\title{
Mathematical Modeling and Classification of Viruses from Herpesvirus Family
}

\author{
Gaber H. Alsayed \\ Basic Sciences Department, \\ Faculty of Engineering Sciences, \\ Sinai University, Egypt.
}

\author{
Ahmed M. Alzohairy \\ Genetics Department, \\ Faculty of Agriculture, Department, Faculty of Engineering, \\ Zagazig University, Egypt Zagazig University, Egypt.
}

\author{
Mohammed M. Saleh \\ Mathematics Department, Faculty of Science, \\ Zagazig University, Egypt
}

\author{
Osama Abdo Mohamed
}

Lecturer of Computer Science, Mathematics Department, Faculty of Science, Zagazig University, Egypt

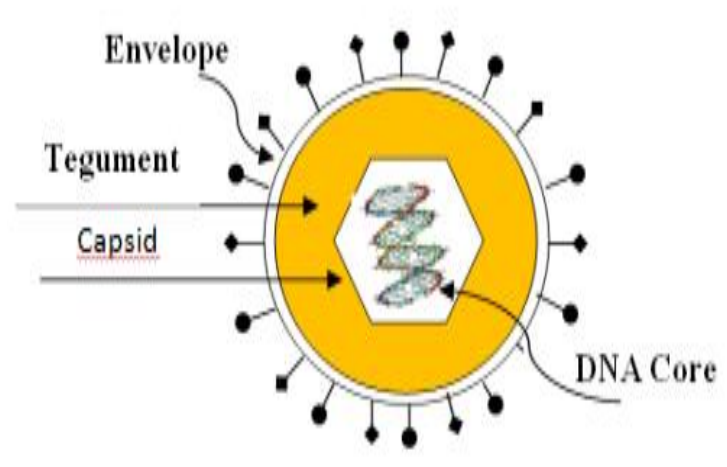

Fig 1: Virus Structure components

Viruses can be classify according to the genome into DNA viruses and RNA viruses.

DNA viruses have the following structures [2]:

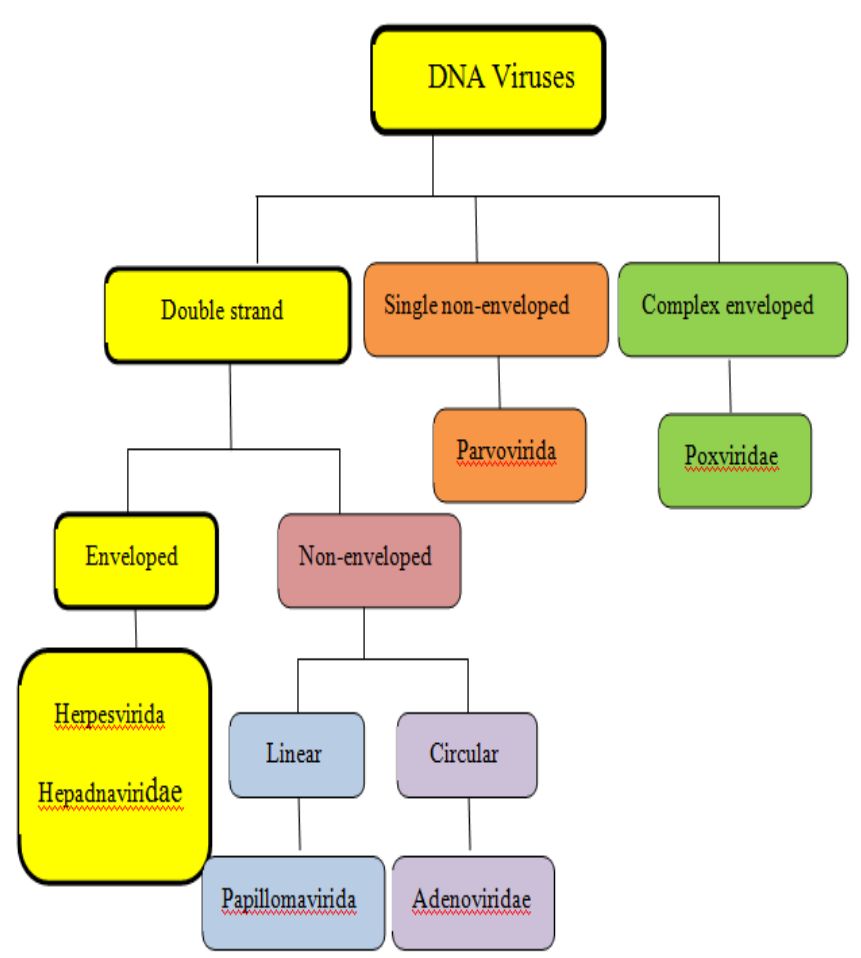

Fig 2: General DNA Virus structure 
Our study focuses on enveloped DNA viruses.

\subsection{Enveloped DNA Viruses}

Enveloped DNA viruses are found in three families [3] as shown in Fig 2 :

1. Herpesviridae (Herpesviruse) family

2. Poxviridae (Boxviruse) family

3. Hepadnaviridae (Hepadnaviruse) family

In this study we will focuses on the first family of enveloped DNA viruses which is herpesviruse family colored in yellow, where we will propose a mathematical model for its life cycle and also we introduces a comprehensive study to classify Herpes-virus family members according to the structure of their capsid protein by use different sequence alignment algorithms.

\subsection{Herpesviridae Family}

Herpesviridae family of viruses comprises enveloped double strand DNA viruses that causes diseases in animals, including humans. Viruses in this family have a double-stranded linear molecular structure with icosahedra symmetry [4][5][6]. Members of this family is known as herpesviruses. The word herpesviruses is derived from the Greek word herpein which refers to the latent and recurring infections phenotype of this family of viruses. This family of viruses contains five species of Herpesviridae which considered dangerous health factor for human health. For instance, HSV-1 and HSV-2 (both of which can cause orolabial herpes and genital herpes), Varicella zoster virus (which causes chicken-pox and shingles), Epstein-Barr virus (which causes mononucleosis) and Cytomegalovirus all of which are considered extremely widespread among humans. There are many reports indicated that at least one of these viruses is infecting $90 \%$, and a latent form of the virus remains in most people [7][8][9]. This family includes eight human pathogens:

- Herpes simplex viruses (HSV) types 1 and 2.

- Varicella-zoster virus (VZV).

- Epstein-Barr virus (EBV).

- Human cytomegalovirus (CMV).

- Human herpes viruses (HHV) types 6,7, and 8.

There are more than 130 known herpesviruses [10], and some are isolated from many organisms such as mammals, birds, fish, reptiles, amphibians, and mollusks [11].

Herpesvirus family contains the following viruses types:-

1. Herpes simplex1 (HSV1)

2. Herpes simplex2 (HSV2)

3. Epstein-barr virus (EBV) or (HHV4)

4. Human herpesvirus6 (HHV6)

5. Human herpesvirus7 (HHV7)

6. Human herpesvirus8 (HHV8)

7. Varicella-zoster virus (VZV)or (HHV3)

8. Human cytomegalovirus (HCMV) or (HHV5)

In this article we will try to classify these viruses according to their capsid protein sequences structure using MatLab algorithms to understand the genetic evolution And the phylogenetic relation of those families.

\section{BIOLOGICAL DATA USED IN THIS STUDY}

All biological data used (which represents the sequences of the capsid protein of the herpesvirus family) was obtained from the protein sequences repository of the national center for biotechnology information (NCBI) and the UniProt Knowledgebase (UniProtKB) which is the central hub for the collection of functional information on proteins. All these data is written in FASTA format which is the most popular format types used in writing sequence for bioinformatics applications, and it is a common format in most biological data bases.

\section{MATHEMATICAL MODELING OF HERPESVIRUS FAMILYLIFE CYCLE}

In this study, we will describe a mathematical model for the herpesviruses virus general life cycles uses the host cell's organelles to replicates new Viruses, which known as Lytic cycle [12]. During this cycle the virus has to infect the cell, So that, the virus attaches itself to the outer cell wall and releases enzymes that weaken the cell wall as shown in Fig 3.

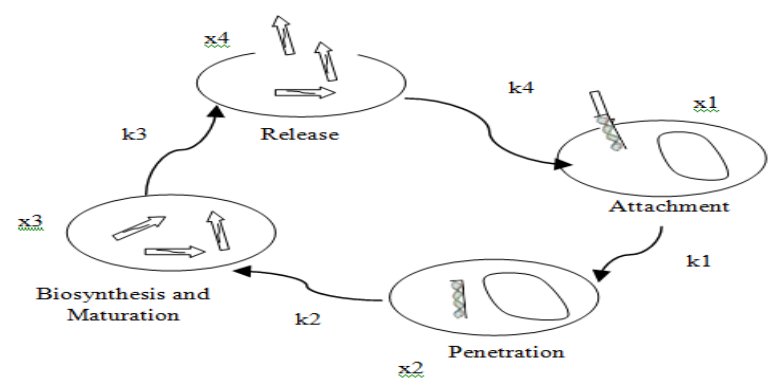

Fig 3: Simple diagram represent herpesviruses Lytic Cycle

The lytic cycle is considered the main cycle in viral replication. As shown in Fig .3, the viral DNA enters the cell and it transcribes itself into the host cell's messenger RNAs and uses them to direct the ribosomes to produce viruses proteins including the capsid protein. The virus takes over the cell's metabolic activities and the host cell's DNA is destroyed . The virus produces progeny phages using the cell energy for its own propagation.. The viruses multiply and the original viruses releases enzymes to break the cell wall. The cell wall bursts, in a process known as lysing. Thus, the new viruses are released [13].

The lytic cycle of a virus consists of six steps [14]. The first two stages, called adsorption and penetration.,. In the adsorption stage, the virus must attaches to a receptor on the cell membrane to be able to enter the cell through the plasma membrane.. In the penetration stage, the virus releases its genetic materials into the cell. This is followed by the integration stage in which the host cell gene expression is arrested, and viral materials are embedded into the host cell nucleus The fourth stage is biosynthesis that the virus uses the cell machinery to make large amount of viral components, and at the meantime, destroys the host's DNA. The last two stages, maturation and lysis where the mature virus particles are formed and released .

In this paper, the basic mathematical model for lytic cycle is proposed in four main stages The model of a lytic cycle is converted into a system of equations. The solution of the equations are solved numerically and described how the lytic phage terminates its infection and breach its host's cell envelope over time $\mathrm{t}$.

Then, the reaction scheme is described in the following four reactions as follows:

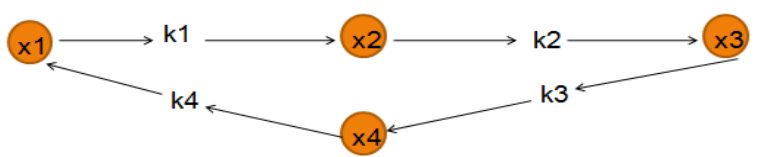


Table 1: This table shows the modeling steps symbols

\begin{tabular}{|r|r|r|r|r|}
\hline $\mathrm{d} / \mathrm{dt}$ & decay & forward & forward & reverse \\
\hline$[\mathrm{x} 1]$ & $-\mathrm{k} 1[\mathrm{x} 1]$ & 0 & 0 & $\mathrm{k} 4[\mathrm{x} 4]$ \\
\hline$[\mathrm{x} 2]$ & $\mathrm{k} 1[\mathrm{x} 1]$ & $-\mathrm{k} 2[\mathrm{x} 2]$ & 0 & 0 \\
\hline$[\mathrm{x} 3]$ & 0 & $\mathrm{k} 2[\mathrm{x} 2]$ & $-\mathrm{k} 3[\mathrm{x} 3]$ & 0 \\
\hline$[\mathrm{x} 4]$ & 0 & 0 & $\mathrm{k} 3[\mathrm{x} 3]$ & $-\mathrm{k} 4[\mathrm{x} 4]$ \\
\hline
\end{tabular}

The dynamics of the system can be written as the following set of first order ODEs:

$$
\begin{aligned}
& \mathrm{d}[\mathrm{x} 1] / \mathrm{dt}=\mathrm{k}_{4}[\mathrm{x} 4]-\mathrm{k}_{1}[\mathrm{x} 1], \\
& \mathrm{d}[\mathrm{x} 2] / \mathrm{dt}=\mathrm{k}_{1}[\mathrm{x}]-\mathrm{k}_{2}[\mathrm{x} 2], \\
& \mathrm{d}[\mathrm{x} 3] / \mathrm{dt}=\mathrm{k}_{2}[\mathrm{x} 2]-\mathrm{k}_{3}[\mathrm{x} 3], \\
& \mathrm{d}[\mathrm{x} 4] / \mathrm{dt}=\mathrm{k}_{3}[\mathrm{x} 3]-\mathrm{k}_{4}[\mathrm{x} 4] .
\end{aligned}
$$

This set of ODEs can be numerically solved by using Matlab program. The numerical solution is computed for some initial values and using ODE45 is given below:

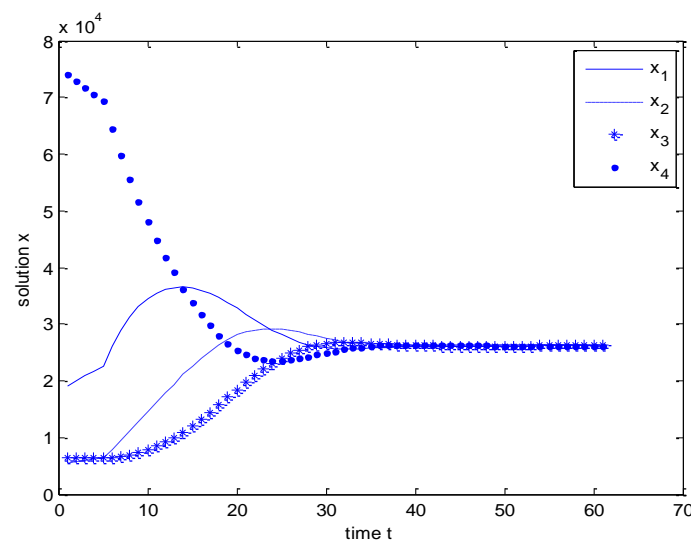

Fig 4: The solution to system of equations produced by ODE45

\section{SEQUENCE ALIGNMENT ALGORITHMS}

Pairwise global alignment algorithms are intended for comparing two sequences. A dynamic programming (DP) algorithm called Needleman and Wunsch [15] was proposed for pairwise global alignment. Those methods are very useful in analysis of DNA and protein sequences [16, 17]. Many new phylogenetic program was developed based on those algorithms [18]. There are other dynamic programming algorithms for pairwise global alignment such as Huang and Chao [19] and NGILA [20]. In addition, there are another algorithms for making pairwise local alignment such as the algorithm introduced by Smith and Michael Waterman [21] and to make multiple sequence alignment MSA [22]. The algorithm which introduced by Thompson et al to make multiple sequence alignment depend on the progressive alignment. This can be done by constructing a succession of pairwise alignment Initially, two sequences are chosen and aligned by standard pairwise alignment; this alignment is fixed. Then, a third sequence is chosen and aligned to the first alignment and this process is iterated until all sequences have been aligned.

The advantage of progressive alignment is that it is fast and efficient, and in many cases the resulting alignments are reasonable $[17,22]$.

\section{PAIRWISE GLOBAL ALIGNMENT (NEEDLEMAN AND CHRISTIAN WUNSCH ALGORITHM)}

In our work we use Needleman and Christian Wunsch algorithm to make pairwise global alignment. This algorithm can be summarized as follows:

1. First we consider any two strings such as

$$
\begin{array}{rl}
A=a_{i} & i=1,2, \ldots, n \\
B=b_{j} & j=1,2, \ldots, m
\end{array}
$$

2. Scoring matrix of size $(n+1)^{*}(m+1)$ is constructed and initialized using a substitution matrix, e.g., PAM (Percent Accepted Mutations) [23], or BLOSUM (Blocks Substitution Matrix) [24].

3. $\mathrm{s}\left(a_{i}, b_{j}\right)=$ score of aligning $a_{i}$ with $b_{j}$

$$
\begin{aligned}
& \mathrm{s}\left(a_{i}, b_{j}\right)= \\
& \left\{\begin{array}{cc}
+1 & \text { if } \mathrm{a}_{\mathrm{i}}=\mathrm{b}_{\mathrm{j}}, \\
-\mu \leq 0 & \text { if } \mathrm{a}_{\mathrm{i}} \neq \mathrm{b}_{\mathrm{j}}, \quad \text { (1) } \\
-\delta \leq 0 \text { (for indels) if } \mathrm{a}_{\mathrm{i}}=-1 \text { or } \mathrm{b}_{\mathrm{j}}=-1 .
\end{array}\right.
\end{aligned}
$$

$-\mu$ and $-\delta$ refer to the score of mismatch and indel respectively.

Indel means insertions or deletions and it can be represented by using the symbol"-".

4. The best alignment is that produces the largest score for $S_{i, j}$ :

$$
S_{i, j}=\max \left\{\begin{array}{l}
S_{i-1, j-1}+s\left(a_{i}, b_{j}\right) \\
S_{i-1, j}-\delta \\
S_{i, j-1}-\delta
\end{array}\right\}
$$

5. The score for elements in the first row and column of the alignment matrix are given by

$$
S_{i, 0}=-i \delta, \quad S_{0, j}=-j \delta
$$

6. The score for the best global alignment of $A$ with $B$ is $S$ (A, $B)=S_{n, m}$, and it corresponds to the highest-scoring path through the matrix and ending at element $(\mathrm{n}, \mathrm{m})$. It is determined by tracing back element by element along the path that yielded the maximum score into each matrix element. This algorithm has time complexity $O(\mathrm{~nm})$.

This algorithm can be briefly summarized as in the following pseudo code:

\section{Global alignment}

Input sequences $\mathrm{A}, \mathrm{B}$

$$
\begin{aligned}
& \text { Set } S_{i, 0} \leftarrow-\delta i \text { for all i } \\
& \text { Set } S_{0, j} \leftarrow-\delta j \text { for all } \mathrm{j} \\
& \text { For i=1 to } \mathrm{n} \\
& \mathrm{J}=1 \text { to } \mathrm{m} \\
& \quad S_{i, j \leftarrow \max \left\{S_{i-1, j}-\delta, S_{i-1, j-1}+s\left(a_{i}, b_{j}\right), S_{i, j-1}-\delta\right\}} \\
& \quad \text { end }
\end{aligned}
$$

end 


\section{DOT-MATRIX OR DOT PLOT METHOD}

Dot matrix or dot plot is an important concept for aligning two sequences.

For example if we have the following two sequences

$$
\begin{aligned}
& s_{1}=\text { ccgtaaagat } \\
& s_{2}=\text { gtgtcaagctaatc. }
\end{aligned}
$$

The dot matrix for aligning $s_{1}$ and $s_{2}$ can be constructed as follow:

First we construct a rectangular $n \times m$ matrix such that the rows corresponding to the characters in the first string $s_{l}$ and columns corresponding to the characters in the second string $s_{2}$, also the order of characters in $s_{1}$ is to the right and is to down in $s_{2}$.

Second a dot is placed in each matrix entry, where a base from $s_{1}$ matches a base from $s_{2}$.

Dot matrix of aligning $s_{1}$ and $s_{2}$ is shown in Fig 5 .

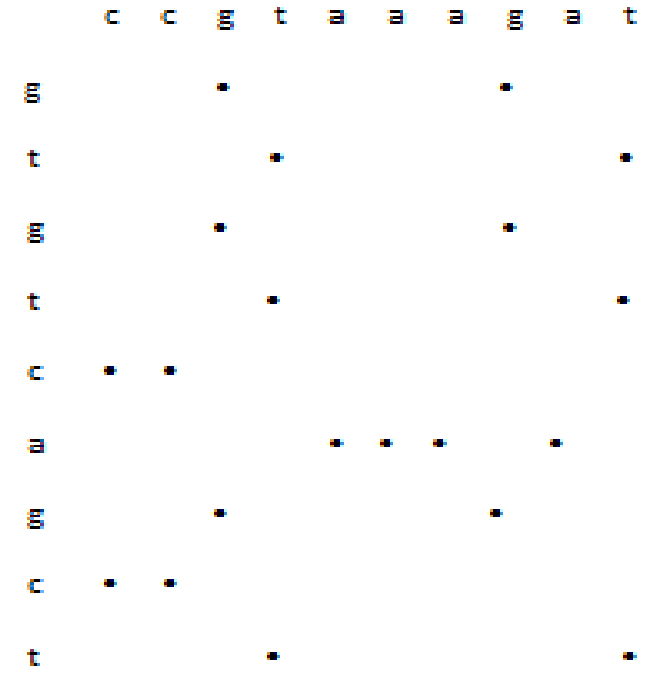

Fig 5: Dot matrix of sequences $s_{1}=$ ccgtaaagat and $s_{2}=$ gtgtcaagctaatc.

The dots show all possible correspondences between the bases of the two sequences $s_{1}$ and $s_{2}$, where each diagonal corresponds to a possible alignment. The best alignment happen when straight line of dots happen at the main diagonal of the dot plot matrix.

\section{RESULTS AND DISCUSSIONS \\ 7.1. Results Of Pairwise Alignment}

First, we have made a code by using MATLAB program to make pairwise global alignment among the entire sequences of herpesviruses family.

\subsubsection{The Results Obtained by Using Sequence Dot Plot Matrix}

Fig 4 to Fig 10 represents the results of global pairwise alignment among the entire sequences of herpesvirus family by using sequence dot plot matrix. These figures are some of figures that obtained when making pairwise global alignment among each pair of viruses of herpesvirus family. We choose the figures that represent the highest similarity and this appear through the straight line of dots that represent the main diagonal in the dot plot matrix where it start from the left upper corner to the right lower corner as shown in figures. This straight line is an indicator for the degree of similarity between the two sequences as we mentioned before in the previous section.

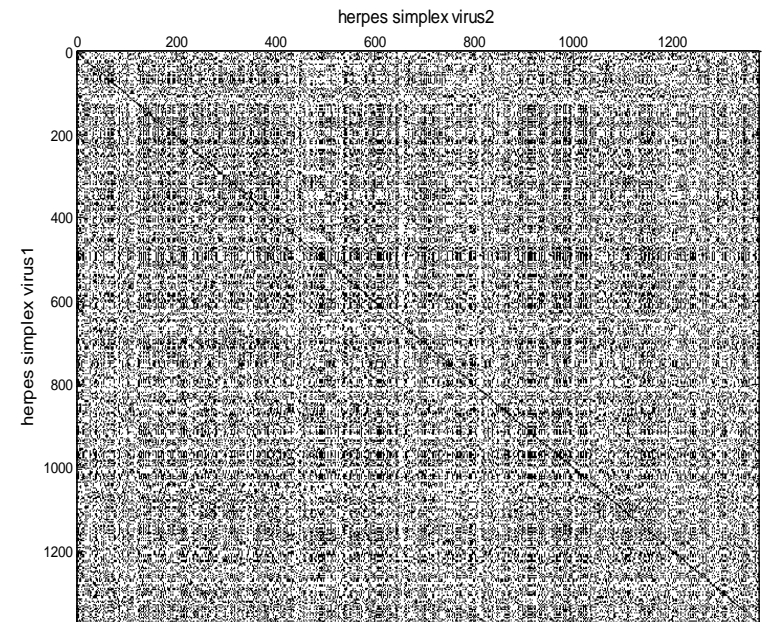

Fig 6: Sequence dot plot matrix between HSV1 and HSV2.

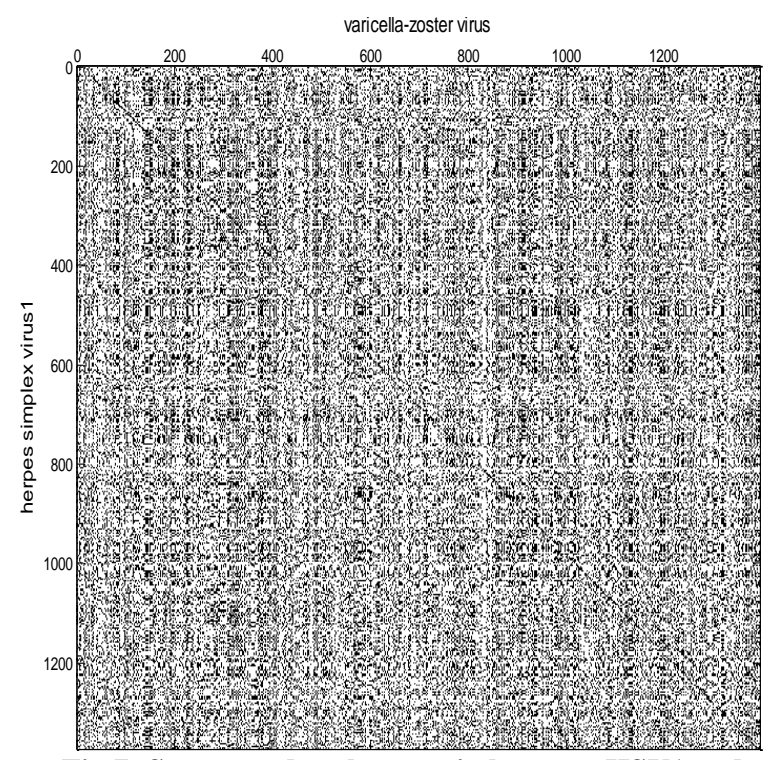

Fig 7: Sequence dot plot matrix between HSV1 and varicella-zoster virus.

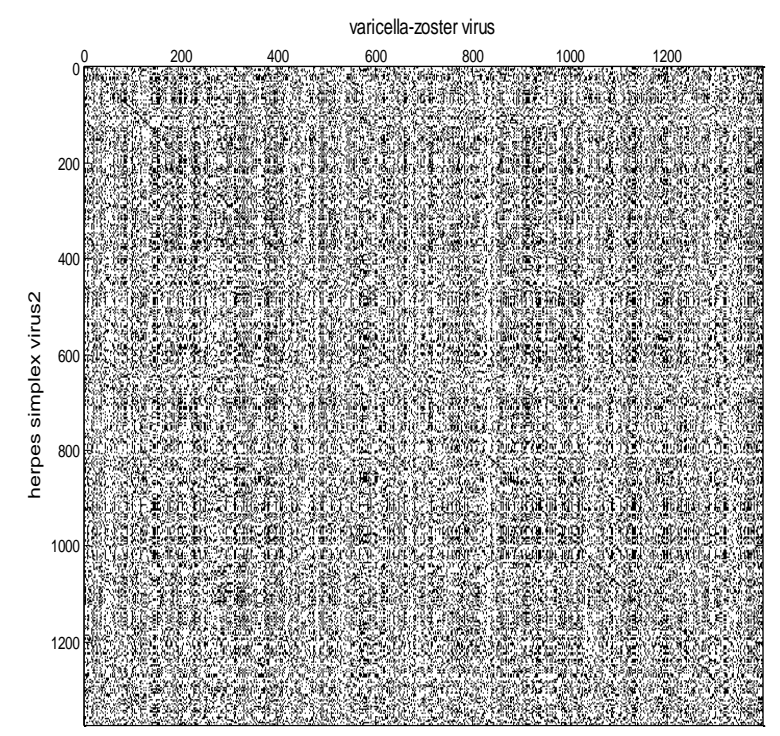

Fig 8: Sequence dot plot matrix between HSV2 and varicella-zoster virus. 
EBV

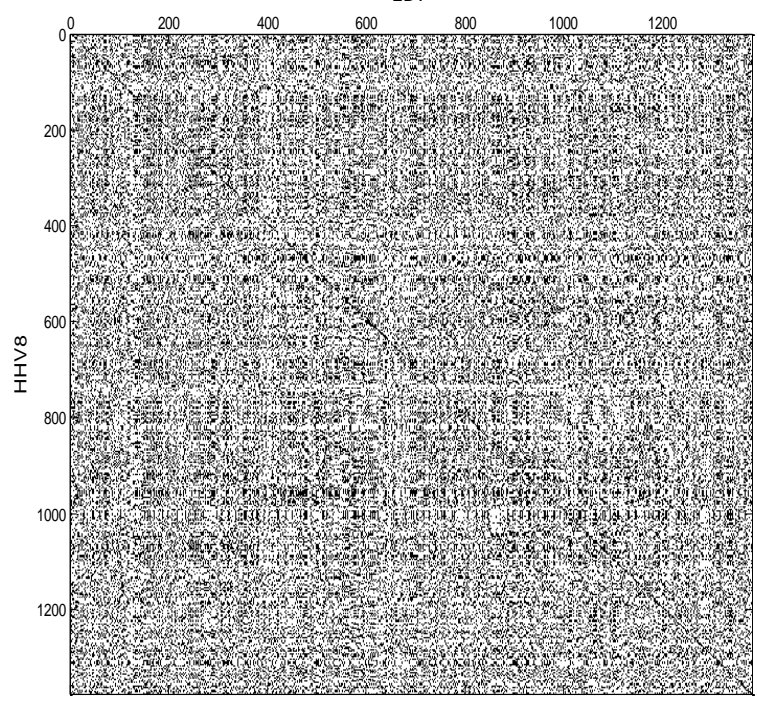

Fig 9: Sequence dot plot matrix between HHV8 and EBV.

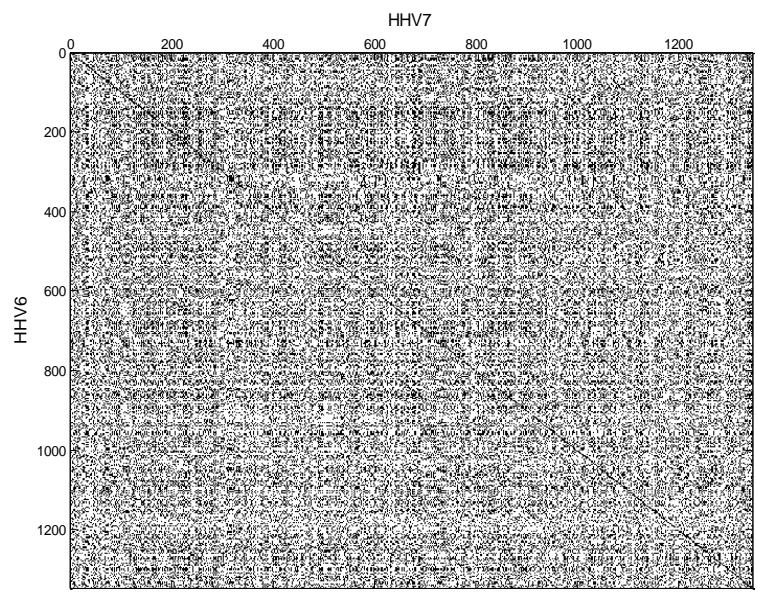

Fig 10: Sequence dot plot matrix between HHV6 and HHV.

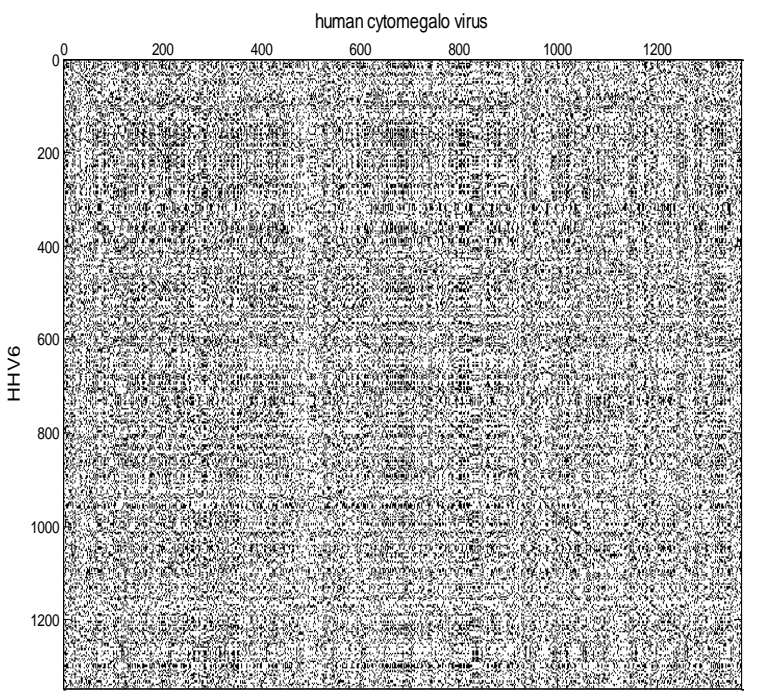

Fig 11: Sequence dot plot matrix between HHV6 and human cytomegalo virus.

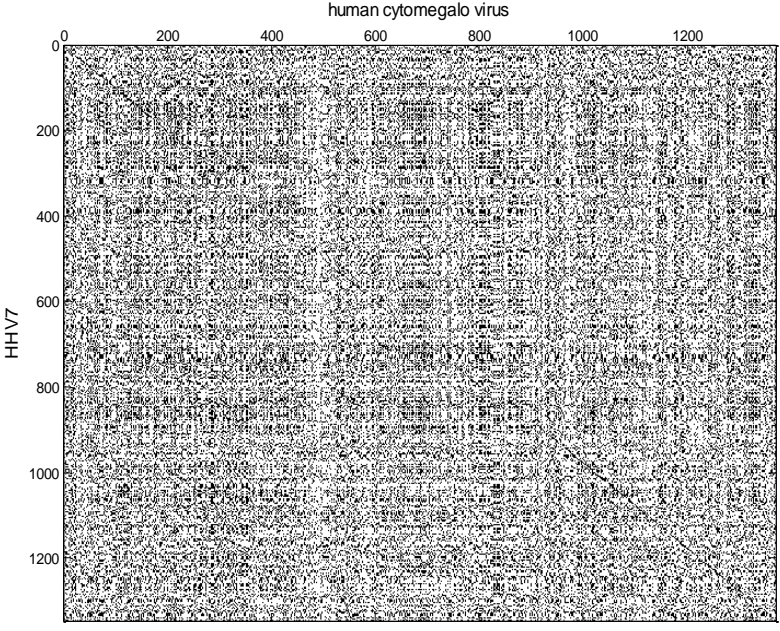

Fig 12: Sequence dot plot matrix between HHV7 and human cytomegalo virus.

\subsubsection{The Results Obtained by Using Needleman-} Wunsch Algorithm

In our study, we have used the following scoring matrices:1-Blosum50

2-Blosum30

The results were as in the following table:-

Table2: This table shows the score and the percentage of similarity (Identities) of the pairwise global alignment among the entire sequences of capsid protein of herpesvirus family.

\begin{tabular}{|l|c|c|c|c|}
\hline $\begin{array}{l}\text { Herpesviruse } \\
\text { Family }\end{array}$ & $\begin{array}{c}\text { Score by } \\
\text { using } \\
\text { Blosum50 }\end{array}$ & $\begin{array}{c}\text { Identit } \\
\text { ies }\end{array}$ & $\begin{array}{c}\text { Score } \\
\text { by using } \\
\text { Blosum } \\
30\end{array}$ & $\begin{array}{c}\text { Identit } \\
\text { ies }\end{array}$ \\
\hline HSV1\& HSV2 & 2940.33 & $94 \%$ & 1848.8 & $94 \%$ \\
\hline HSV1 \& EBV & 537.333 & $29 \%$ & 423.2 & $28 \%$ \\
\hline HSV1 \& HHV6 & 503 & $26 \%$ & 392 & $26 \%$ \\
\hline HSV1 \& HHV7 & 480 & $25 \%$ & 373 & $25 \%$ \\
\hline HSV1\& HHV8 & 573.667 & $31 \%$ & 438.8 & $30 \%$ \\
\hline $\begin{array}{l}\text { HSV1\& Varicella- } \\
\text { Zoster Virus }\end{array}$ & 1641.67 & $52 \%$ & 1061.4 & $52 \%$ \\
\hline $\begin{array}{l}\text { HSV1\& Human } \\
\text { Cytomegalo Virus }\end{array}$ & 468.667 & $28 \%$ & 375.4 & $27 \%$ \\
\hline EBV \& HSV2 & 541.667 & $28 \%$ & 431.4 & $28 \%$ \\
\hline EBV\& HHV6 & 747.667 & $31 \%$ & 533.8 & $31 \%$ \\
\hline EBV\& HHV7 & 726.667 & $32 \%$ & 517.4 & $31 \%$ \\
\hline EBV\& HHV8 & 1780 & $56 \%$ & 1128.6 & $56 \%$ \\
\hline $\begin{array}{l}\text { EBV \& Varicella- } \\
\text { Zoster Virus }\end{array}$ & 551.667 & $28 \%$ & 412.8 & $27 \%$ \\
\hline $\begin{array}{l}\text { EBV \& Human } \\
\text { Cytomegalo Virus }\end{array}$ & 722.667 & $30 \%$ & 507.8 & $30 \%$ \\
\hline HSV2 \& HHV6 & 493.667 & $26 \%$ & 392.2 & $26 \%$ \\
\hline
\end{tabular}




\begin{tabular}{|l|c|c|c|c|}
\hline HSV2 \& HHV7 & 472 & $24 \%$ & 372.8 & $25 \%$ \\
\hline HSV2\& HHV8 & 568 & $30 \%$ & 436.6 & $30 \%$ \\
\hline $\begin{array}{l}\text { HSV2 \& Varicella- } \\
\text { Zoster Virus }\end{array}$ & 1635 & $52 \%$ & 1060 & $52 \%$ \\
\hline $\begin{array}{l}\text { HSV2\& Human } \\
\text { Cytomegalo Virus }\end{array}$ & 470.333 & $27 \%$ & 377 & $27 \%$ \\
\hline HHV6 \& HHV7 & 2182.67 & $68 \%$ & 1371.4 & $68 \%$ \\
\hline HHV6\& HHV8 & 707 & $30 \%$ & 500.2 & $30 \%$ \\
\hline $\begin{array}{l}\text { HHV6\& Varicella- } \\
\text { Zoster Virus }\end{array}$ & 466.667 & $26 \%$ & 371.4 & $26 \%$ \\
\hline $\begin{array}{l}\text { HHV6 \& Human } \\
\text { Cytomegalo Virus }\end{array}$ & 1400.33 & $44 \%$ & 899.8 & $44 \%$ \\
\hline HHV7 \& HHV8 & 710.667 & $31 \%$ & 498 & $31 \%$ \\
\hline $\begin{array}{l}\text { HHV7 \& Varicella- } \\
\text { Zoster Virus }\end{array}$ & 458 & $27 \%$ & 359 & $26 \%$ \\
\hline $\begin{array}{l}\text { HHV7 \& Human } \\
\text { Cytomegalo Virus }\end{array}$ & 1395.33 & $43 \%$ & 893 & $44 \%$ \\
\hline $\begin{array}{l}\text { HHV8 \&Varicella- } \\
\text { Zoster Virus }\end{array}$ & 555 & $29 \%$ & 412.4 & $29 \%$ \\
\hline $\begin{array}{l}\text { HHV8 \& Human } \\
\text { Cytomegalo Virus }\end{array}$ & 711.333 & $30 \%$ & 506 & $30 \%$ \\
\hline $\begin{array}{l}\text { Varicella-Zoster } \\
\text { Virus \& Human } \\
\text { Cytomegalo Virus }\end{array}$ & 432.667 & $26 \%$ & 347.2 & $26 \%$ \\
\hline
\end{tabular}

\subsubsection{Result obtain by using the scoring matrix BLOSUM60}

MSA of herpesvirus family by using scoring matrix blosum60

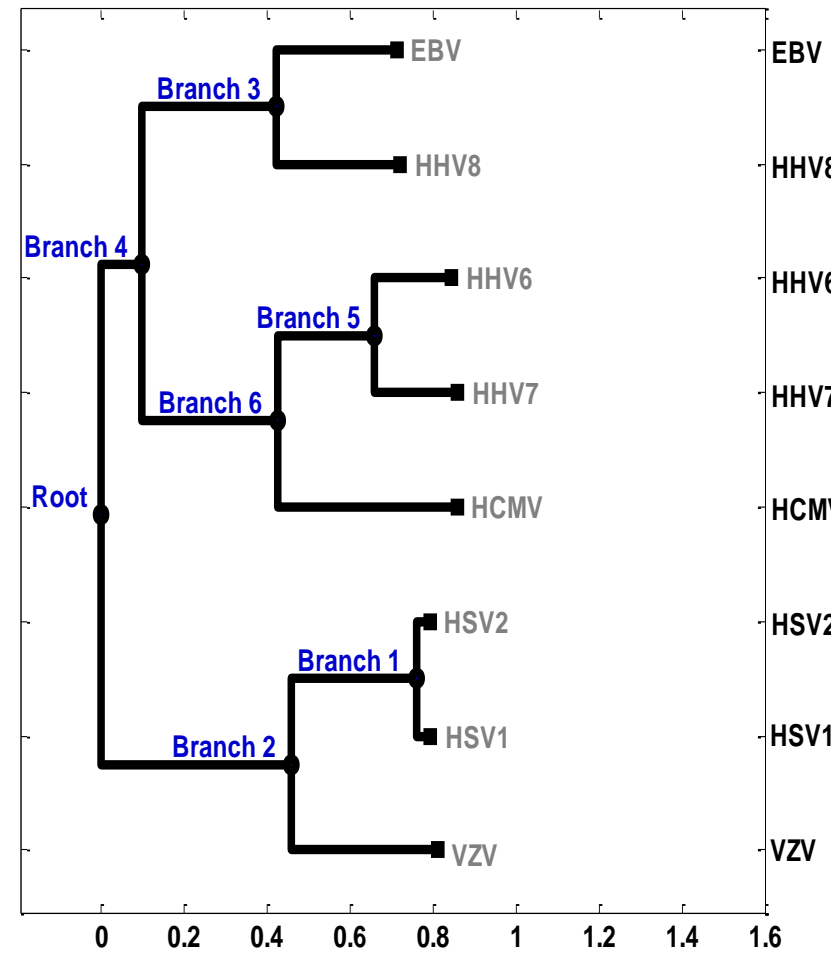

The results obtained in table 2 and figures from Fig 6 to Fig 12 conclude that:-

1. Capsid protein of herpes simplex 1 is more similar to capsid protein of herpes simplex 2 and also capsid protein of varicella-zoster virus.

2. Capsid protein of herpes simplex 2 is more similar to capsid protein of varicella-zoster virus.

3. Capsid protein of Epstein barr virus is more similar to capsid protein of human herpes virus8.

4. Capsid protein of human herpes virus6 is more similar to capsid protein of human herpes virus7 and also capsid protein of human cytomegalo virus.

5. Capsid protein of human cytomegalo virus is more similar to capsid protein of human herpes virus7.

\subsection{Results Of Multiple Sequence Alignment}

Second, we have made a code by using MATLAB program to create multiple sequence alignment (MSA) among all the entire sequences of the capsid protein sequence. Multiple sequence alignment (MSA) is used to ensure and specify the results obtained in Table 1. The results are illustrated by using phylogenetic tree.

In our study, we have used the following scoring matrices:-

$$
\begin{array}{ll}
\text { 1- } & \text { Blosum60 } \\
\text { 2- } & \text { Blosum30 } \\
\text { 3- } & \text { PAM10 }
\end{array}
$$

Fig 13: Results of MSA among the entire sequences of herpesvirus family by using the scoring matrix BLOSUM60

\subsubsection{Result obtain by using the scoring matrix BLOSUM 30}

The result obtained when using scoring matrix BLOSUM30 is typical to that of BLOSUM60.

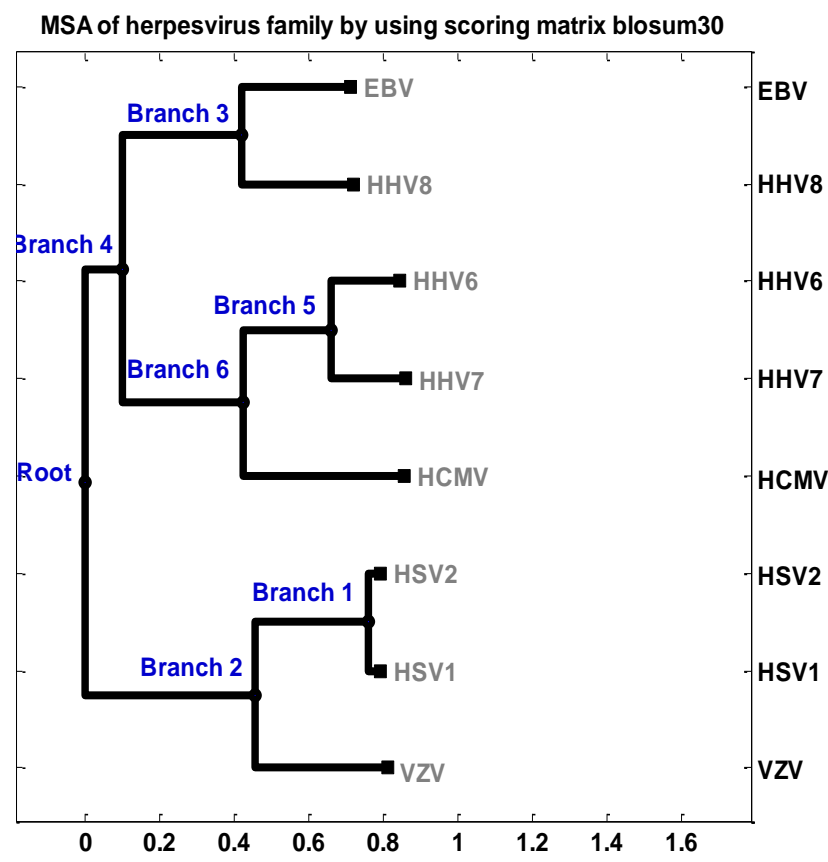

Fig 14: Results of MSA among the entire sequences of herpesvirus family by using the scoring matrix BLOSUM30. 


\subsubsection{Result obtain by using the scoring matrix PAM10}

The result obtained when using scoring matrix PAM10 is typical to that of BLOSUM60 and BLOSUM30.

MSA of herpesvirus family by using scoring matrix PAM10

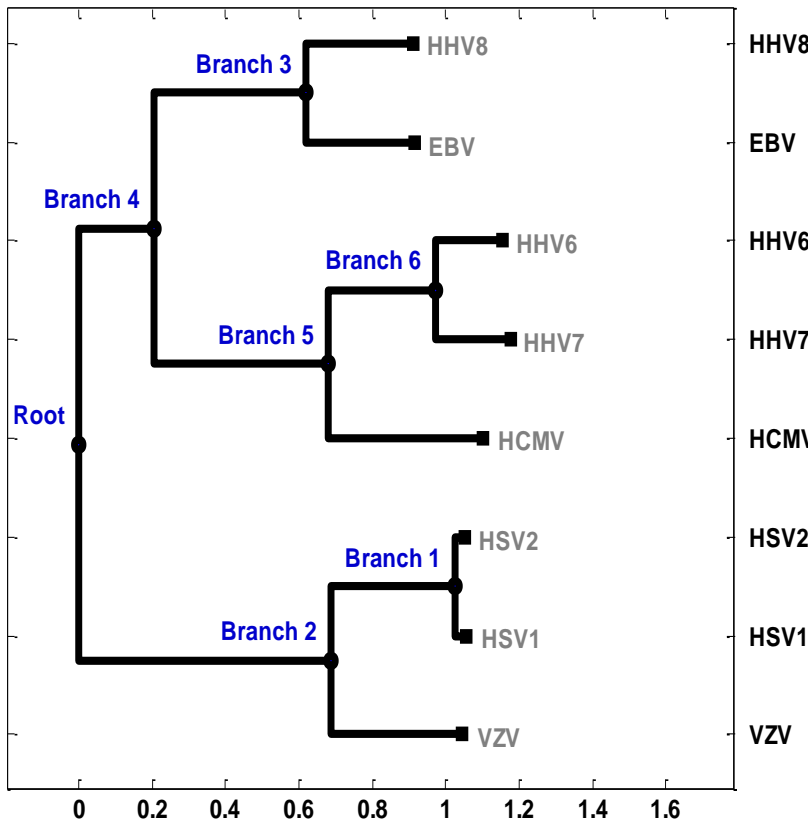

Fig 15: Results of MSA among the entire sequences of herpesvirus family by using the scoring matrix PAM10.

\section{CONCLUSION}

From the previous results obtained in figures from Fig 6 to 15 and Table1we can classify the herpesvirus family according to the similarity of the structure of their capsid protein into three categories as follows:-

1. The first category contain

a) Herpes simplex virus1 (HSV1)

b) Herpes simplex virus2 (HSV2)

c) Varicella-zoster virus VZV (HHV3)

2. The second category contain

a) Human herpesvirus7 (HHV7)

b) Human herpesvirus8 (HHV6)

c) Human cytomegalo virus HCMV (HHV5)

$3 . \quad$ The third category contain

a) Human herpesvirus8 (HHV8)

b) Epstein barr virus (EBV)

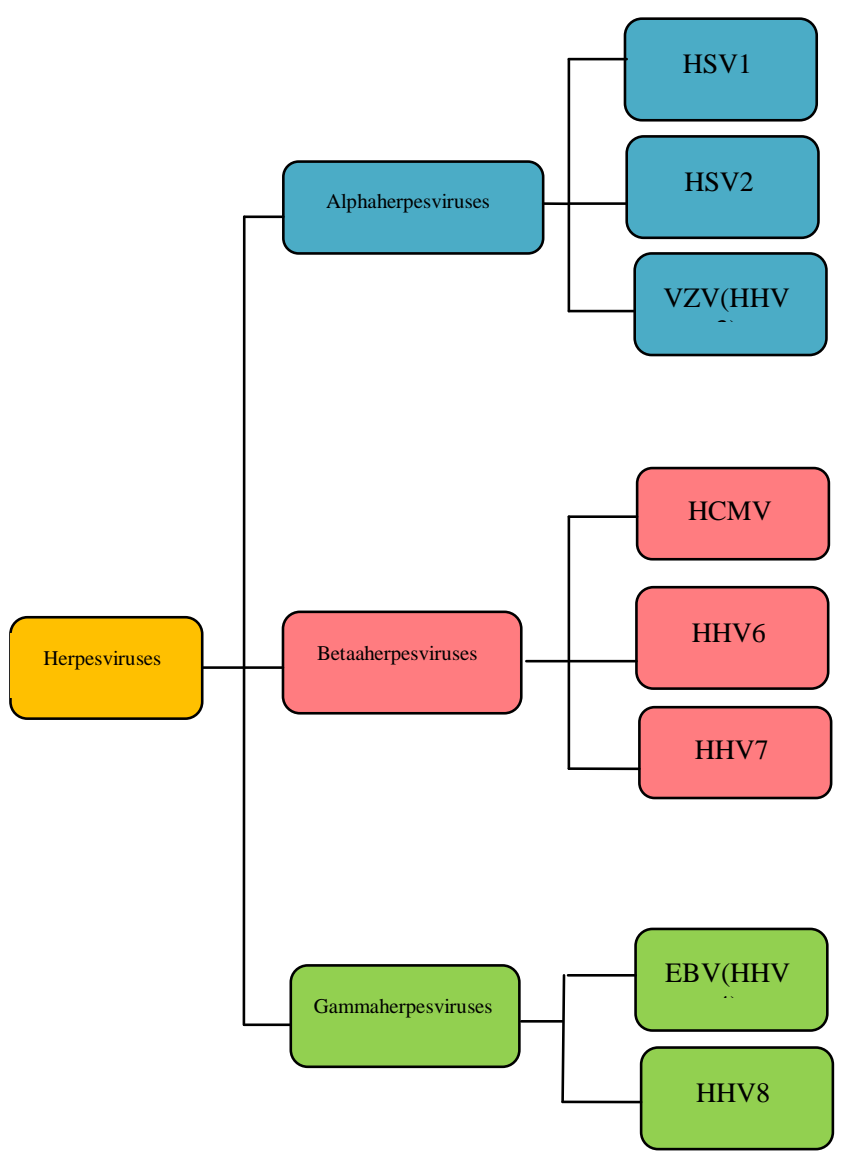

The differences in capsid gene activation and expression need to be studies in depth by analysis it's promoter region [25]. In addition, the structure similarity and evolutionary relationship between those viruses family and Genomic Retrotransposon based on structure [26, 27] and activation [28, 29, 30, 31] is currently under investigation.

\section{ACKNOWLEDGMENTS}

The Authors would like to thank the H3ABioNet project, NIH Common Fund project number U41HG006941, for supporting the developing Egyptian node and funding their scientific activities and research.

\section{REFERENCES}

[1] Amon, Wolfgang; Farrell (November 2004). "Reactivation of Epstein-Barr virus from latency". Reviews in Medical Virology 15 (3): 149-56. doi:10.1002/rmv.456. PMID 15546128. Retrieved 28 May 2012.

[2] Volk et al, "essential of medical microbiology" $4^{\text {th }}$ edition 1991.

[3] Richard A. Harvey, Pamela C. Champe, Bruce D. Fisher "Lippincott's microbiology 2th Edittion" Section 4 Chapter 25, (2007).

[4] Ryan KJ; Ray CG (editors) "Sherris Medical Microbiology (4th ed.) ". McGraw Hill. ISBN 0-8385-8529-9. (2004).

[5] Mettenleiter et al. "Molecular Biology of Animal Herpesviruses". Animal Viruses: Molecular Biology. Caister Academic Press. ISBN 1-904455-22-0. . (2008). [http://www.horizonpress.com/avir]. 
[6] Sandri-Goldin RM (editor). " Alpha Herpesviruses: Molecular and Cellular Biology". Caister Academic Press. ISBN 978-1-904455-09-7. (2006). [23].

[7] Chayavichitsilp P, Buckwalter JV, Krakowski AC, Friedlander SF. "Herpes simplex". Pediatr Rev 30 (4): 11929; quiz 130. doi:10.1542/pir.30-4-119. PMID 19339385. April 2009.

[8] In the United States, as many as $95 \%$ of adults between 35 and 40 years of age have been infected. National Center for Infectious Diseases

[9] Staras SA, Dollard SC, Radford KW, Flanders WD, Pass RF, Cannon MJ (November 2006). "Seroprevalence of cytomegalovirus infection in the United States, 19881994". Clin. Infect. Dis. 43 (9): 1143-51. doi:10.1086/508173. PMID 17029132. Retrieved 2009-1204.

[10] Jay C. Brown, William W. Newcomb. "Herpesvirus Capsid Assembly: Insights from Structural Analysis". Current Opinion in Virology 1 (2): 142-149. 2011 August 1.

[11] John Carter, Venetia Saunders. "Virology, Principles and Applications". John Wiley \& Sons. ISBN 978-0-47002386-0.

[12] Madigan M, Martinko J (2006). Brock Biology of Microorganisms (11th ed.). Prentice Hall. ISBN 0-13144329-1.

[13] N. Komarova, D. Wodarz, ODE models for oncolytic virus dynamics, J of Theoretical Biology, 263(2010) 530-543.

[14] Y Wang, JP Tian, J Wei. Lytic cycle: A defining process in oncolytic virotherapy. Applied Mathematical Modelling, Vol. 37, Issue 8, 15 April 2013, Pages 5962-5978

[15] C. S. B Needleman, C. D. Wunsch, "A general method applicable to the search for similarities in the amino acid sequence of two proteins". Journal of molecular biology, vol. 48, no. 1, pp. 443-453. 1970.

[16] Mohammed M. Saleh, Ahmed M. Alzohairy, Osama Abdo Mohamed, Gaber H. Alsayed (2013). A Comprehensive Study by Using Different Alignment Algorithms to Demonstrate the Genetic Evolution of Heat Shock Factor 1 (HSF1) in Different Eukaryotic Organisms. IRACST Engineering Science and Technology: An International Journal (ESTIJ), ISSN: 2250-3498, Vol.3, No.2 Pages:376382

[17] Mansour A, Jaime A. Teixeira da Silva, Gábor Gyulai (2009) Assessment of molecular (dis) similarity: The role of multiple sequence alignments (MSA) programs in biological research. Genes, genomes and genomics. 3 (Special Issue 1): 23-30 (Print ISSN 1749-0383) (Bioinformatics SI)

[18] Mohamed Issa, Hitham Abo Bakr, Ahmed M. Alzohairy and Ibrahim Zeidan (2012) Gene-Tracer: Algorithm Tracing Genes Modification from Ancestors through Offsprings. in International Journal of Computer Applications (IJCA) 52(19):11-14

[19] X. Huang, K. M. Chao, "A generalized global alignment algorithm, Bioinformatics", Vol. 19, №2: (2003), p228233.

[20] R. A. Cartwright: Ngila, "global pairwise alignments with logarithmic and affine gap costs", Bioinformatics, Vol. 23, $\mathrm{N}^{\circ} 11$ :, p1427-1428. (2007).
[21] T. F. Smith, M. S. Waterman, "Identification of common molecular subsequences", J. Molecular Biology, no. 147, pp. 195-197, 1981.

[22] Thompson J. D., Higgins D. G., Gibson T. J., CLUSTAL W" improving the sensitivity of progressive multiple sequence alignment through sequence weighting, positionspecific gap penalties and weight matrix choice" Nucleic Acids Res, vol. 22. pp. 4673-4680, (1994).

[23] M. O. Dayhoff, R. M. Schwartz, B. C. Orcutt, "A model of evolutionary change in proteins, in Atlas of Protein Sequence and Structure", chapter 22, National Biomedical Research Foundation, Washington, DC: (1978), p345-358.

[24] S. Henikoff, J. G. Henikoff, "Amino acid substitution matrices from protein blocks", Proc. Natl. Acad. Sci. USA Vol. 89, N²2: (1992), p10915-10919.

[25] Alzohairy, A. Mansour, Margaret H. MacDonald, Benjamin F. Matthews (2013). The pJan25 vector series: An enhancement of the gateway-compatible vector pGWB533 for broader promoter testing applications. Plasmid (2013), 69(3):249-56

[26] Alzohairy, A. Mansour. Gábor Gyulai, Jansen RK. A. Bahieldin (2013) Transposable Elements Domesticated and neofunctionalized by Eukaryotic Genomes PLASMID. 69 (2013) $1-15$

[27] Mansour, A. (2008). Utilization of Genomic Retrotransposon as cladistic molecular markers. Journal of Cell and Molecular Biology. 7(1): 17-28.

[28] Mansour, A. Epigenetic activation of Genomic Retrotransposon (2007). Journal of Cell and Molecular Biology. 6 (2): 99-107

[29] Mansour A. (2009). Water Deficit Induction of Copia and Gypsy Genomic Retrotransposons. Plant Stress 3(1)33-39

[30] Alzohairy, A. Mansour , Mohamed A Yousef, Sherif S Edris, Balázs Kerti and Gábor Gyulai (2012). Detection of long terminal repeat (LTR) retrotransposons reactivation induced by in vitro environmental stresses in barley (Hordeum vulgare) via reverse transcription-quantitative polymerase chain reaction (RT-qPCR). Life Science Journal (2012; 9(4): 5019-5026.

[31] Ahmed Alzohairy, J.S.M. Sabir, Gabor Gyulai, Rania Younis, Robert Jansen, Ahmed Bahieldin (2014) Environmental Stress Activation of Plant LTRRetrotransposons. Functional Plant Biology. (In press 2014)

\section{AUTHORS' PROFILE}

Gaber Hassan Alsayed Ahmed, BSC of Math and Computer Science in 2007 from Faculty of Science, Zagazig University, Egypt. He is working as A research Assistant in Basic Sciences Department, Faculty of Engineering Science, Sinai University, Egypt.

Dr. Ahmed Mansour Mohamed Mansour Alzohairy, Ph.D (2000-2005) in (Plant Signal transduction), Thesis entitled (Manipulation of Genetic information in studying plant performance) from Faculty Of agriculture, Zagazig University.

Currently he is working as Assistant professor of Genetics and Agricultural Genetic Engineering in Faculty of Agriculture, Zagazig University.He has published 14 papers in bioinformatics. 
Dr. Osama Abdo Mohamed is assistant professor in King abd El-Aziz University. He has got Msc. Degree in computer science in. 1998 \& PH.D. degree in computer science in 2007. He has more than 17 years teaching experience and more than 17 years research experience in the field of signal processing and logic programming. He has published more than 10 national and international research papers in various refereed journals

Dr. Mohamed Mohamed Saleh, Ph.D. (1984-1985) in Integral Equations from Mathematics Departement, Faculty of Science,
Zagazig University. Currently he is working as Assistant Professor Mathematics Departement, Faculty of Science, Zagazig University, Egypt.

Dr. Rania Bahgat Mohamed Amer Ph.D. (2004-2009) in differential geometry from, Zagazig University Faculty of Engineering Department of Physics and Mathematics, she is working as lecturer in Department of Physics and Mathematics Zagazig University Faculty of Engineering. 